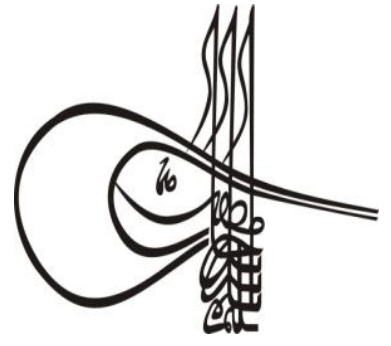

Received/Geliş: 17.09.2019

\section{Tutkish Studies \\ Social Sciences}

Volume 14 Issue 5, 2019, p. 2303-2323

DOI: 10.29228/TurkishStudies.37053

ISSN: 2667-5617

Skopje/MACEDONIA-Ankara/TURKEY

Research Article / Araştırma Makalesi

Article Info/Makale Bilgisi

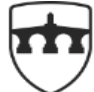

INTERNATIONAL BALKAN UNIVERSITY

EXCELLENCE FOR THE FUTUR IBU.EDU.MK

This article was checked by iThenticate.

\title{
TÜRK BANKACILIK SEKTÖRÜNDE TÜREV ÜRÜN KULLANIMDA ETKİLİ OLAN FAKTÖRLERİN ANALİŻ̇
}

\author{
Serdar KUZU* - İsmail Erkan ÇELİK**
}

\begin{abstract}
öz
$\mathrm{Bu}$ çalışmanın amacı Türk bankacılık sektöründe türev ürün kullanımı açısından en büyük payı oluşturan döviz swap işlemleri üzerine etki edebilecek makroekonomik değișkenlerin etkilerini belirlemektir. Bankaların türev ürün kullanımına etki eden makroekonomik değişkenlerin belirlenmesi, bankacılık sektörü türev ürün kullanım dinamiklerinin ortaya konması açısından büyük önem taşımaktadır. Çalışmada makroekonomik değişkenler ile döviz swap işlemleri arasında bir ilişkinin olup olmadığını ve döviz swap kullanımında hangi makroekonomik değișkenlerin etkili olabileceği panel veri analizi ile ortaya koyulmaya çalışılmıştır. Çalışmada bağımsız değişkenlerin belirlenmesinde literatür çalışmalarının yanı sıra döviz swap miktarını etkileyebilecek değişkenler dikkate alınmıștır. Yapılan literatür çalışmaları sonucunda bağımsız değişkenler olarak piyasa riski, faiz oranı, kur volatilitesi, bilanço dışı riskler, enflasyon ve bankaların TL mevduatları olarak belirlenmiştir.

Yapılan literatür çalışmaları sonucunda bağımsız değişkenler olarak piyasa riski, faiz oranı, kur volatilitesi, bilanço dişı riskler, enflasyon ve bankaların TL mevduatları olarak belirlenmiştir. Araștırmanın sonucunda Döviz swap miktarı kullanımını negatif yönde etkileyen değişkenlerin bilanço dişı riskler, bankaların TL mevduatları ve enflasyon iken, pozitif yönde etkileyen değişkenler ise piyasa riski ve kur riski olduğu ortaya çıkmıştır. Faiz oranı ile döviz swap kullanımı arasında istatistiki olarak anlamlı bir sonuç bulunamamıştır.
\end{abstract}

Çalışmada kullanılan parametrelerin yapılan literatür çalışmalarında, hem yurt içi hem de yurtdışında yapılan analizlerde

Dr. Öğr. Üyesi, İstanbul Üniversitesi, E-posta: serdarkuzuu @ hotmail.com

Dr. Öğr.Üyesi, Doğuş Üniversitesi, E-posta: ismailerkancelik@ gmail.com 
farklı etkileri olduğu görülmüştür. Bu farklılıklar; çalışmaya konu olan dönemlerdeki ekonomik konjonktür, ülkelerin ekonomik yapıları, bankacılık sektörünün mali yapısı ve bankacılık sektörüne ait uygulamada ki farkl1liktan kaynaklanabilmektedir. Son y1llarda hem Türkiye'de hem de yurtdışı piyasalarda yaşanan gelişmeler sonucunda Türk bankacilık sektörü döviz swap işlemleri ile ilgili makroekonomik parametrelerin ilişki ortaya koyulması, bankacilık sektörü karar vericileri açısından çalışmanın yararlı olabileceği düşünülmektedir.

Anahtar Kelimeler: Türev Ürünler, Panel Veri Analizi, Türk Bankac1lık Sektörü, Döviz Swap1

\title{
ANALYSIS OF FACTORS EFFECTIVE IN DERIVATIVE PRODUCT USE IN TURKISH BANKING SECTOR
}

\begin{abstract}
The aim of this study is to determine the effects of macroeconomic variables that may affect foreign exchange swap transactions, which constitute the largest share of derivative products in Turkish banking sector.

The determination of macroeconomic variables that affect the use of derivative products of banks is of great importance in terms of revealing the dynamics of derivative product use of the banking sector. In this study, it is tried to determine whether there is a relationship between macroeconomic variables and foreign currency swap transactions and which macroeconomic variables can be effective in foreign currency swap usage by panel data analysis. In the study, independent variables were determined in addition to literature studies and variables that could affect the amount of foreign currency swaps. As a result of the literature studies, market risk, interest rate, exchange rate volatility, off-balance sheet risks, inflation and TL deposits of banks were determined as independent variables.

As a result of the literature studies, market risk, interest rate, exchange rate volatility, off-balance sheet risks, inflation and TL deposits of banks were determined as independent variables. As a result of the study, the variables that negatively affect the use of foreign currency swap amount were off-balance sheet risks, TL deposits of banks and inflation, while the variables that positively affected were market risk and exchange rate risk. No statistically significant result was found between interest rate and foreign currency swap usage.

In the literature studies, it was found that the parameters used in the study had different effects in both domestic and international analyzes. These differences; The economic conjuncture in the periods subject to the study may result from the differences in the economic structures of the countries, the financial structure of the banking sector and the practice of the banking sector. In recent years, both in Turkey and also as a result of developments in yurdişina markets, Turkish banking sector foreign currency swaps related to manifest the relationship of macroeconomic parameters, it is thought that the banking sector might be useful to work in terms of decision-makers.
\end{abstract}




\section{STRUCTURED ABSTRACT}

Aim: The determination of macroeconomic variables that affect the use of derivative products of banks is of great importance in terms of revealing the dynamics of derivative product use of the banking sector. The aim of this study is to determine the effects of macroeconomic variables that may have an impact on foreign currency swap transactions, which constitute the largest share of derivative products in the Turkish banking sector.

Method(s): In the model, macroeconomic variables which are thought to be the degree of explanation on foreign currency swaps of the Turkish banks are included in the analysis and the related model is analyzed within the framework of pooled regression model. Panel data analysis can be modeled in different ways depending on the assumptions about constant, slope and error term. Panel data analysis is estimated using either the Pooled OLS, Fixed Effects and Random Effects approaches. When the unit and time effects are homogeneous, the error term does not include both effects, the pooled least squares method gives efficient and consistent estimators, the same parameters for all horizontal cross-sectional units, where the constant parameter differs between the units. If the (SE) approach and slope parameters vary between horizontal sections and the units in the sample are randomly selected, the Random Effects (RE) approach is used. Assuming that the relationship between the study currency swaps and other variables is stable, the pooled least squares method of the most appropriate method is preferred.

Findings: As a result of the analysis, statistically significant relations were found with the use of foreign currency swap amount except interest rate variable. The variables that negatively affect the use of foreign currency swap amounts are off-balance sheet risks, TL deposits of banks and inflation, while the variables that positively affect market risk and exchange rate risk.

When the results obtained from the study are compared with the literature studies, it is observed that there are studies that reveal any meaningful, meaningless, positive and negative relationship between off-balance sheet risks and derivative product and it is observed that derivative product use decreases when the off-balance sheet risk increases as a result of the use of derivative product. This result was realized in accordance with the expectations and meaningful in our study.

In our related model, a negative and significant relationship was found between inflation and derivative product use. In literature studies, Hassan and Khasawneh (2009); Although anbar and Alper (2011) did not find any relationship between them and Bailey and Chan (1993) found a positive relationship, the study found a negative relationship between inflation and foreign exchange swap use in line with expectations. This situation coincides with the increasing use of derivatives held for trading their study results in order to obtain yields of banks in the period in which the decline in inflation in Turkey.

Another variable is the exchange rate volatility and the amount of exchange swap in the use of Shiu et al. (2012) found a positive relationship and Yip and Nguyen (2012) found no significant 
relationship, but a positive and significant relationship was found in our study. In this case, in addition to being compatible with expectations, especially in Turkey, especially foreign-currency swaps to hedge for banks in cases where there is high volatility was observed most of the time they apply. Especially negativities experienced in macroeconomic conditions in Turkey in recent days, political instability the country has led to more risky start seeing through the eyes of foreigners. Foreigners tried to meet their TL needs in the London swap market because they did not want to borrow with the currency of a more risky country. However, the limitations imposed on swap transactions caused liquidity squeeze in TL and caused swap rates to increase. It should be noted here that the control of exchange rates and interest rates is not linked to short-term operational practices but to factors such as stability, production, democracy and employment.

The increase in the total TL deposits of banks reduces the risk premium and is seen as a confidence factor for banks in times of possible volatility. Especially recently, the banks' resistance uses trading derivative products despite the rise in TL deposits as a result of delivering high returns on interest banking sector in Turkey in order to increase their profitability by diversifying their income to a chance this increase arttırabilecekk that these opportunities tepip only currency risk, despite constant currency demands create and foreign currency amounts increases the exchange rate constantly high.

Conclusion: As a result of the analyzes conducted in the study, it was found that macroeconomic factors affect the use of derivatives. In addition, when derivative product use and macroeconomic variables are considered, it is seen that the derivative product use of Turkish banking sector is used for trading rather than hedge purpose.

Panel data analysis was used to determine the factors affecting the use of derivative products in the Turkish banking sector in order to determine the macroeconomic variables affecting the use of foreign exchange swaps, which have the largest share in derivative products. As a result of the analyzes conducted in the study, it was observed that all macroeconomic parameters except interest rate affect the use of foreign currency swaps. In the literature studies, it was found that the parameters used in the study had different effects in both domestic and international analyzes. These differences; The economic conjuncture in the periods subject to the study may result from the differences in the economic structures of the countries, the financial structure of the banking sector and the practice of the banking sector.

Keywords: Derivatives, Panel Data Analysis, Turkish Banking Sector, Currency Swap.

\section{Giriș}

Son otuz yılda matematik ve teknolojide yaşanan atılımlar, finansal piyasalar ve risk yönetiminin gelişiminde önemli bir rol oynamaktadır. Bu gelişmeler sonucunda özellikle türev ürünler ve diğer finansal yeniliklerin oluşumunu mümkün kılmıştır. Dünyada ve Türkiye'de yaşanan birçok krizle birlikte, finansal sistemde risklerin boyutunun ne kadar büyük bir etkiye sahip olduğunu ortaya çıarak, finansal piyasalarda riskin azaltılması ve yönetilmesi ile ilgili yapılan risk yönetim uygulamalarının önemini daha da etkin hale gelmiştir. Finansal yenilikler, finansal krizler, bilgi 
teknolojilerinde yaşanan hızlı gelişmeler ve birçok finansal kurumun iflaslarıyla birlikte risk yönetim olgusunun değerlendirilmesinde bir takım farklı ölçme ve değerlendirme teknikleri yer almaya başlamıştır. Türkiye'de son zamanlarda finansal kurumların mali tablolarında yer alan türev ürün kullanımında ki artış, kurumların mali yapılarında risk yönetimi konusuna giderek daha önem verdiklerinin göstergesi niteliğini taşımaktadır. Türev ürünlerin kullanılma amaçlarından biri riskin bertaraf edilmesi bir diğer amaç ise riskin azaltılmasıdır. Burada temel amaç türev ürün kullanımıyla birlikte riskin gerçekleşmesi durumunda katlanılacak maliyeti optimum seviyede tutmaktır

Finansal sistemin temel işlevlerinden biride risk yönetimi için gerek duyulan ürün ve uygulamaları sağlamaktır. Risk yönetimini üç yöntemi vardır. Bunlar, korunma (hedging), portföy çeşitlendirmesi ve sigortadır. Bu yöntemlerden korunma ve portföy çeşitlendirmede kullanılan risk yönetim uygulamalarının önemli bir kısmını temsil eden türev ürünler etkin ve düşük maliyetli araçlardır.

Silber (1983), finansal yeniliklerin arkasında işletmelerin gerek piyasa veya işletmenin kendi şartları gerekse yasal düzenlemeler sonucu karşılaştıkları finansal sınırlamaları azaltma çabasını görmektedir (Silber, 1983). Örneğin yüksek fiyat oynaklığına karşı türev ürünlerin kullanılması bu tür bir çabadır. Van Horne (1985) ise yeni bir ürünün gerçek ve kalıcı bir yenilik olabilmesi için finansal sistemin etkinliğinin arttırılması gerektiğini, başka bir ifadeyle yeni bir ürünün uzun vadede kalıcı olabilmesi için piyasayı tamamlayıcı nitelikte olması gerektiğini ifade etmiştir (Horne, 1985).

Riskten kaçınan işletme risk felsefesini oluştururken, olası hasarların etkisini sigorta/reasürans, türev ürünleri ya da bu ürünlerin karışımını da içeren çeşitli araçlardan biri ile yaymak istemektedir. Günümüzde finans piyasalarında enstrüman çeşitliliğinin artması ve bazı finansal kuruluşların özellikle türev ürünleri içeren pozisyonlarından dolayı iflas etmeleri finans piyasasında doğru ve güvenilir risk yönetim tekniklerinin ortaya çıkmasında önemli bir rol oynamıştır (Jorion, 2011).

1970’li yıllarında uluslar arası para sisteminin çökmesi sonucunda ortaya çıkan döviz kurlarındaki volatilite hareketleri ve para piyasalarındaki değişim sonucu ortaya çıkan faiz oranlarındaki değişiklikler, kur ve faiz risklerini önemli seviyelere getirmiştir. Ayrıca emtia ve hisse senedi fiyatlarında ki yaşanan dalgalanmalar fiyat riskini de ortaya çıkarmıştır. Yaşanan bu gelişmeler doğrultusunda bu risklerin bertaraf yada elemine etmek için türev ürünler geliştirilmiştir. Bu ürünler sayesinde katlanılacak risklere karşı risk yönetiminde yeni olanaklar geliştirilmiş ve finansal piyasada ürün çeşitliliği arttırmıştır. Yaşanan bu gelişmeler doğrultusunda özellikle 1980'li yılından itibaren teknolojinin gelişmesi ile birlikte bilgiye ulaşma ve bilginin daha etkin kullanımı sağlanmıştır. Yaşanan bu değişim ve finansal deregülasyona tepki olarak türev ürünleri piyasası hızlı bir gelişim göstererek günümüzde 2018 y1lı haziran sonunu itibariyle tezgah üstü türev ürünlerin toplam değeri 639 trilyon \$'a ulaşmıştır. Türev ürün enstrümanları forward, futures, swap ve opsiyon, olarak bilinmektedir. Türev ürünler üç farklı kullanım amaçlı olarak kullanılmakta olup bunlar hedge, spekülatif ve arbitraj amaçlı kullanımlarıdır.

Önceden öngörülmeyen risklerden korunma yolları olan hedging, işletmelerin faaliyetlerinden doğan kur risklerinin ortadan kaldırılması için düzenlenen vadeli işlemlerdir. Hedging bir risk yaratma değil, risk önleme işlemidir. Hedging faaliyetleri aynı zamanda risk yönetim faaliyetleri olarak ta ifade edilmekte olup, bu faaliyetlerin temel amacı küçük bir maliyete katlanarak olası büyük bir zarardan kaçınmaktır. Arbitraj fiyat farlılığından yararlanarak kar elde etmek durumudur. Çoğu hedge fon da arbitraj fırsatını bularak kazanç sağlamaktadır. Hedge fonlar türev ürünler kullanarak yüksek kaldıraç oranıyla faaliyet göstermektedir. Türen ürünlerle yapılan kaldıraçlı yatırımlar bilanço dışı işlemlerdir. Spekülasyon amaçlı kullanım ise fiyat değişimlerini tahmin ederek kazanç sağlamaya yönelik türev ürün kullanımıdır. 


\section{Türev Ürünler}

Türev ürünler, belli tutardaki standart bir malın ya da menkul kıymetin işlem anında belirlenmiş fiyattan, belirli bir yerde ve belirli bir tarihte satın alınmasını ya da satılmasını sağlayan araçlardır. Türev ürünlerin fiyatları başka bir ürünün fiyatına bağlı olarak değişir. Opsiyon, forward, futures ve swaplar türev ürün olarak bilinir. Söz konusu ürünler riskten korunma, spekülasyon ve arbitraj amacıyla kullanılır (Berk, 2007). Türev ürünleri genel olarak işlem gördükleri yerlere göre iki başlık altında ele alınmaktadır. Bunlardan ilki genellikle forward ve swap işlemlerini kapsayan ve tezgah üstü işlemler (OTC) olarak adlandırılan ve düzenli piyasaları bulunmayan bir başka deyişle düzenli bir borsada işlem görmeyen finansal ürünlerdir. İkincisi ise futures ve opsiyon işlemlerini kapsayan, düzenli piyasaları bulunan ve borsada işlem gören finansal ürünlerdir.

Bankacılık sektörünün asli faaliyetlerine odaklanması özellikle piyasalarda belirsizliklerin giderilmesi, bankacılık sektöründe fiyat oluşumu ve faiz oranların gelecekte nasıl bir durum sergileyeceği açısında türev ürün piyasaları büyük önem arz etmektedir.

Tezgah üstü piyasalar (OTC) borsaların önemli bir alternatifi olup, bu piyasalar işlem hacmi yönünden ölçüldügüünde organize piyasalardan daha büyüktür. Türev sözleşmelerinin büyük bir çoğunluğu OTC piyasalarında işlem görmektedir. Bu işletmeler açısından bazen dezavantaj yaratabilmektedir. Örneğin bilanço dışı işlemlerin bulunmadığı bir durumda işletmenin bilançosu, işletmenin risk düzeyi hakkında genel bir fotoğraf sunar. OTC piyasaların da işlem gören türev sözleşmelerinin çoğu bilanço dışı işlem niteliği taşıdıklarından dolayı bu sözleşmeleri kullanan işletmeler bilançolarına bakıp risk düzeylerini belirleme hususunda yanlış kararlar alabilmektedir (Active, 2009).Türev piyasalar Dünyada büyük tutarda işlem hacmine sahip olup, gün geçtikçe bu piyasalar hızla büyümeye devam etmektedir. Bankacılık sektöründe türev ürün kullanımı açısından futures, forward, opsiyon ve swap sözleşmeleri yer almasına karşın en çok kullanılan sözleşmelerin ise swap sözleşmeleri olduğu görülmektedir.

Futures, ileri bir tarihte önceden belirlenen fiyat, miktar ve nitelikte; ekonomik veya finansal göstergeyi, sermaye piyasası aracını, malı, kıymetli madeni veya dövizi alma veya satma yükümlülüğü getiren sözleşmedir. Futures piyasası işletmeleri arzu edilmeyen fiyat değişimlerine karşı bir koruma görevi üstlenmektedir (Dubofsky, 2001).

Forward, satıcının belli bir ürünü ileri bir tarihte, belirlenen bir fiyat üzerinden alıcıya teslim etmesini öngören sözleşmelerdir. Sözleşmenin şartları alıcı ile satıcı tarafından karşılıklı belirlenmektedir. Forward kontratlar nispeten daha basit türev sözleşmeleridir. Türev ürünler içinde hacim ve işlev olarak büyük yer tutan forward işlemlerin tamamı OTC piyasalarında gerçekleşmektedir.

Swap, iki işletme arasında gelecekteki borç anapara taksitlerinin değiş-tokuş etmek için yapılan bir sözleşmedir. Bu sözleşmede nakit akışlarının ödeneceği tarih ile bunların hesaplanacağı yöntem tanımlanmaktadır. Nakit akışlarının hesaplanması genellikle faiz oranı, döviz kuru ya da diğer piyasa değişkeninin gelecekteki değerini kapsamaktadır. Swap sözleşmeleri bir borçlanma veya yatırım yöntemi olmayıp sadece mevcut borçların veya yatırımların nakit akımlarını değiştirmeye yarayan finansal araçlardır

Opsiyon (option), bir varlık veya malın belirlenmiş bir fiyattan belirli bir vadede ya da vade süresi içinde alma veya satma hakkı doğuran sözleşme olarak ifade edilmektedir. $\mathrm{Bu}$ tanımda vurgulanması gereken nokta bir opsiyonun uygulanmasının zorunluluk değil bir tercih konusu olmasıdır. Bir mali araç olarak opsiyon sözleşmeleri ise döviz, faiz oranları, tarımsal mallar ve öteki ekonomik varlıklar üzerinde yapılabilir. 


\section{Bankacılık Sektöründe Türev Ürün Kullanımı}

Bankacılık sektörü gelecekteki belirsizlik açısından karlı çıkabilmek ve hedge amaçlı türev ürünleri kullanmaktadırlar. Bundan dolayı türev ürün kullanımı gün geçtikçe işlem hacmiyle birlikte $\operatorname{arttığı~ve~gelişmelere~bağlı~olarak~yeni~ürünler~ortaya~çıkmaktadır.~}$

Dünyada yaşanan birçok finansal krize baktığımızda işletmelerin portföylerinde ve finansal yapılarında yaşanan bozukluklar, türev piyasalarda yapılan işlemlere karşı pozisyon alınmamasından dolayı finansal işletmeler büyük kayıplarla karşı karşıya kalmışlardır. Özellikle 2008 küresel finansal krize baktığımızda; konut fiyatlarındaki aşırı yükselişler, ipotek kredilerinde yaşanan yapısal bozulmalar, faiz vade yapısının bozulması, türev piyasa ürünleri kullanımının genişlemesi, kredi derecelendirme kurumlarının kurumların portföyünde yer alan riskli menkul kıymetlerin değerini düşürmesi, yeniden değerlemeyle birlikte riskli menkul kıymetlerin piyasa değerlerinin defter değerinin altına düşmesi ve fonlamada yaşanan sıkışıklık gibi bir takım gelişmeler birçok işletmeyi iflas noktasına kadar getirmiştir. Yaşanan gelişmeler karşısında işletmeler maruz kaldıkları riskleri belirleyebilmek, yeniden tanımlayabilmek ve bu risklere karş1 türev piyasalarda karşı pozisyon alınarak riskin sınırlandırılması konusu daha da önem arz etmeye başlamıştır. 1996 yılına itibariyle dünyada 20 trilyon \$'a ulaşan türev ürün kullanımının değeri, 2018 yılı haziran sonu itibariyle 639 trilyon \$'a ulaşmıştır. Bu tutar işletmelerin mali yapılarında risk yönetimi konusunda gittikçe artan bir şekilde önem verdiklerinin göstergesi niteliğini taşımaktadır. Türkiye'de ise vadeli işlem ve opsiyon borsasında ki yapılan türev işlemler, nominal olarak artışı ve ürün çeşitliliğinde ki artış ile önemli seviyelere ulaşmıştır.

Günümüzde küresel açıdan bakıldığında, türev ürün piyasalarının gelişmesinde etkili olan faktörleri aşağıda ki gibi sıralamak mümkündür. Bunlar (Active, Bankacılık ve Finans Dergisi, 2009);

* Finansal piyasalarda yaşanan deregülasyon süreci yeni yatırım firsatları doğurmuş bu durum artan riskler için yeni ürünlerin geliştirilmesine yardımcı olması

* Gelişmiş ve gelişmekte olan piyasalarda işlem yapan kurumsal yatırımcıların, bu ülkelerde ki karşılıklı ilişkilerinden doğan riskleri ortadan kaldırılması gerekliliği

* Serbest piyasa ekonomilerindeki ekonomik birimlerin maruz kaldıkları mal fiyatları ile faiz oranı volatilesi için uygun korunma araçlarına ihtiyaç duyulmuştur.

Türev ürünler uygun risk teknikleri ile uygulanması ve rasyonel olarak kullanıldığ 1 takdirde riski bertaraf etme ve korunma açısından oldukça etkili sonuçlar verebilmektedir. Türev araçlar öncelikle emtia piyasalarında daha sonrada yaygın olarak finansal piyasalarda kullanılmaya başlanmıştır. Bu araçlar; alım-satım (trading), riskten korunma (hedging) ve süpekülatif işlemlerini gerçekleştirmek amaacıyla kullanılmaktadır. Türev ürün piyasalarında alınacak pozisyonların (net kar/zarar pozisyonlarının), spot piyasada ki varlık veya yükümlülüklerin değerinin aksi yönünde alınmasıyla risk azaltılmış ya da önlenmiş olur.

Dünyada bankalar türev ürünlerin en önemli kullanıcılarındandır. Çünkü bankaların ana faaliyet konuları mevduat toplama ve kredi verme faaliyetleri olduğundan dolayı bankalar çeşitli finansal risklere maruz kalabilmektedirler. Bankalar, türev ürünlerin işlem gördüğü piyasalarda spot piyasadaki mevcut veya gelecekte planladıkları pozisyona eşit ve tersi yönde bir pozisyon alarak aktif ve pasif pozisyonlarını hedge edebilmektedirler. Bu durumda fiyatların ne yönde hareket ettiği önemini yitirmekte ve bir piyasadaki kazanç (kayıp) diğer piyasadaki kayıpla (kazançla) telafi edilmektedir. Türk bankacılık sektöründe türev ürün kullanımı ağırlıklı olarak alım satım amaçlı yapılmaktadır. Özellikle son dönemlerde Türkiye'de kurda yaşanan volatilite hareketleri sonucunda artan kur riski ve hem yurtiçinde hem de yurtdışında yaşanan gelişmeler sonucunda bankaların maruz kaldıkları riskler artmış ve buna bağlı olarak riskten korunma amaçlı türev ürün kullanımı artmıştır. 
Grafik 1: Türk Bankacılık Sektörü Türev Finansal Varlık Tutarlarının Yıllar İtibariyle Gelişimi (2010-2019 Mart Dönemi)

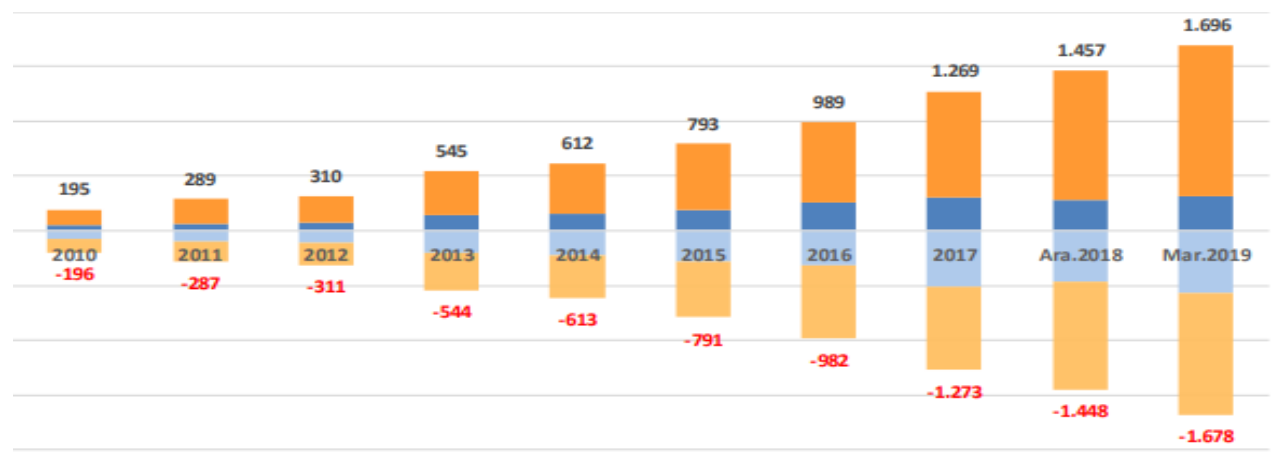

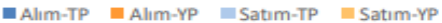

Kaynak: https://www.bddk.org.tr/ContentBddk/dokuman/duyuru_0689_01.pdf (06.06.2019)

Grafik 1, 2010-2019 mart Türk bankacılık sektörü türev finansal varlık tutarlarının yıllar itibariyle gelişimini ortaya koymaktadır. Yıllar itibariyle artan risklere karşılık türev ürün varlık tutarının arttığı gözlemlenmektedir. Mart 2019 dönemi itibarıyla türev alım tutarı 1.696 milyar TL, türev satım tutarı 1.678 milyar TL olarak gerçekleşmiştir

Grafik 2: Türev İşlemlerin Dağılımı

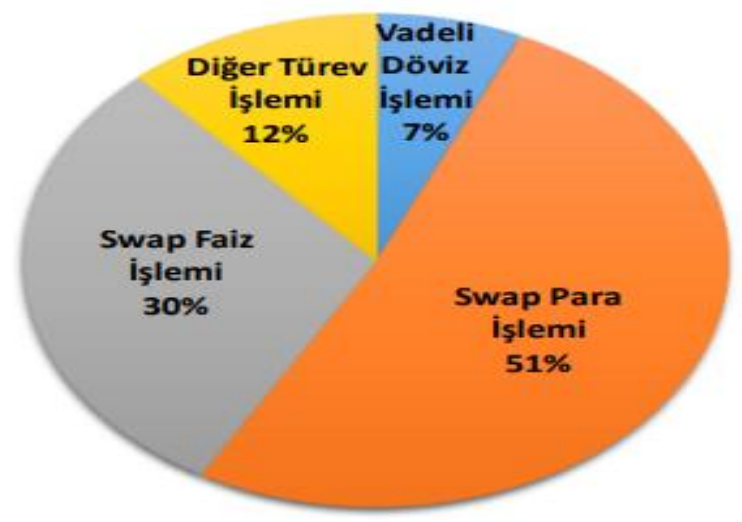

Kaynak: https://www.bddk.org.tr/ContentBddk/dokuman/duyuru_0689_01.pdf

Grafik 2'de Türkiye'de türev işlem dağılımına bakıldığında 2019 yılı mart ayı sonu itibariyle düzenlenmiş olan Bilanço dışında yer alan türev işlemlerin \%51'i swap para işlemlerinden, \%30'u swap faiz işlemlerinden oluşmaktadır. Türk bankacılık sektöründe türev ürün kullanıma bakıldığında Grafik 2'de yer alan verilere göre ağırlıklı olarak en çok swap para işlemleri, sonrasında ise swap faiz işlemleri olduğu görülmektedir. Türk bankacılık sektörü türev ürün işlem hacminin 2006-2018 yılları arasındaki gelişimi Grafik 3'te gösterilmiştir 
Grafik 3: Türk Bankac1lık Sektörü Türev Ürün İşlem Hacminin Yıllar İtibariyle Gelişimi (Milyon TL)

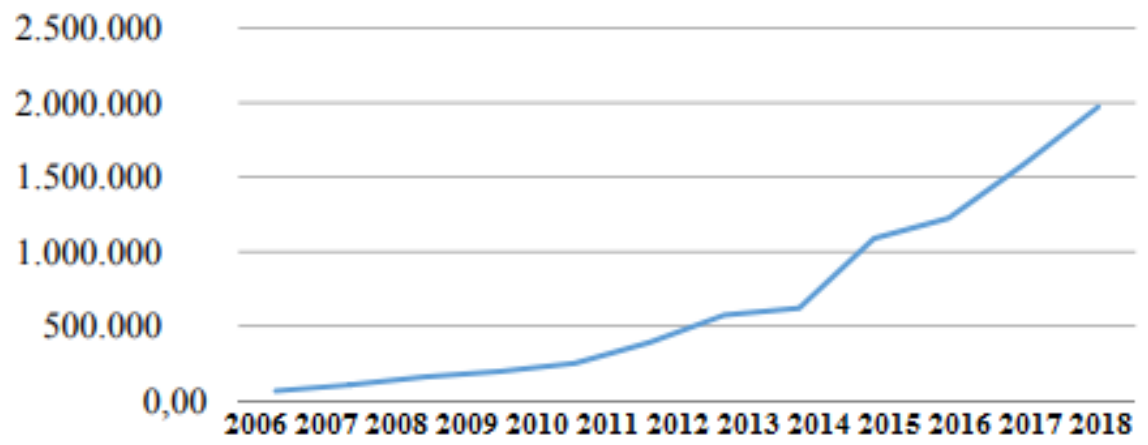

Kaynak: TBB elde edilen veriler çerçevesinde oluşturulmuştur.

Tük bankacılık sektöründe türev ürün kullanımı genellikle risk korunma amacından ziyade alım satım amaçlı kullanılmaktadır. Fakat son zamanlarda Türkiye'de yaşanan gelişmeler sonucunda kurda ki volatilite hareketleri özellikle riskten korunma amaçlı türev ürün kullanımı kayda değer bir şekilde arttırmıştır. Yıllar itibariye Dünya da ve Türkiye'de yaşanan makroekonomik şartlara göre türev ürün hacminin son zamanlarda artış göstermektedir. Özellikle 2014 y1lında itibaren küresel risk algısıyla birlikte türev ürün kullanımında kayda değer bir artış göstermesinde makroekonomik faktörler dışında bankaya özgü faktörlerde etkili olabileceği düşünülmektedir. Özellikle dövize dayalı türev ürün kullanımı 2019 yılı nisan ayı verilerine göre TL cinsi türev ürün 527.735 milyon USD, yabancı para (YP) cinsi türev ürün toplamı ise 1.252.704 milyon USD civarındadır. Grafik 4'te yılları arası Türk bankacılık sektörü türev ürün işlem hacminin para birimi itibarıyla gelişimi Yıllar itibariyle baktığımızda dövize dayalı işlem hacminin, TL'ye göre işlem hacmine göre arttığ 1 görülmektedir. Dövize dayalı türev ürün hacminde ki artış hem riskten korunma (özellikle kur riski) hem de spekülatif amaçlı yani fiyat farklılıklarında yararlanıp kar elde etme amaçlı tercih edildiği görülmektedir.

Grafik 4: 2010-2018 Yılları Arası Türk Bankacılık Sektörü Türev Ürün İşlem Hacminin Para Birimi İtibarıyla Gelişimi (Milyon \$)

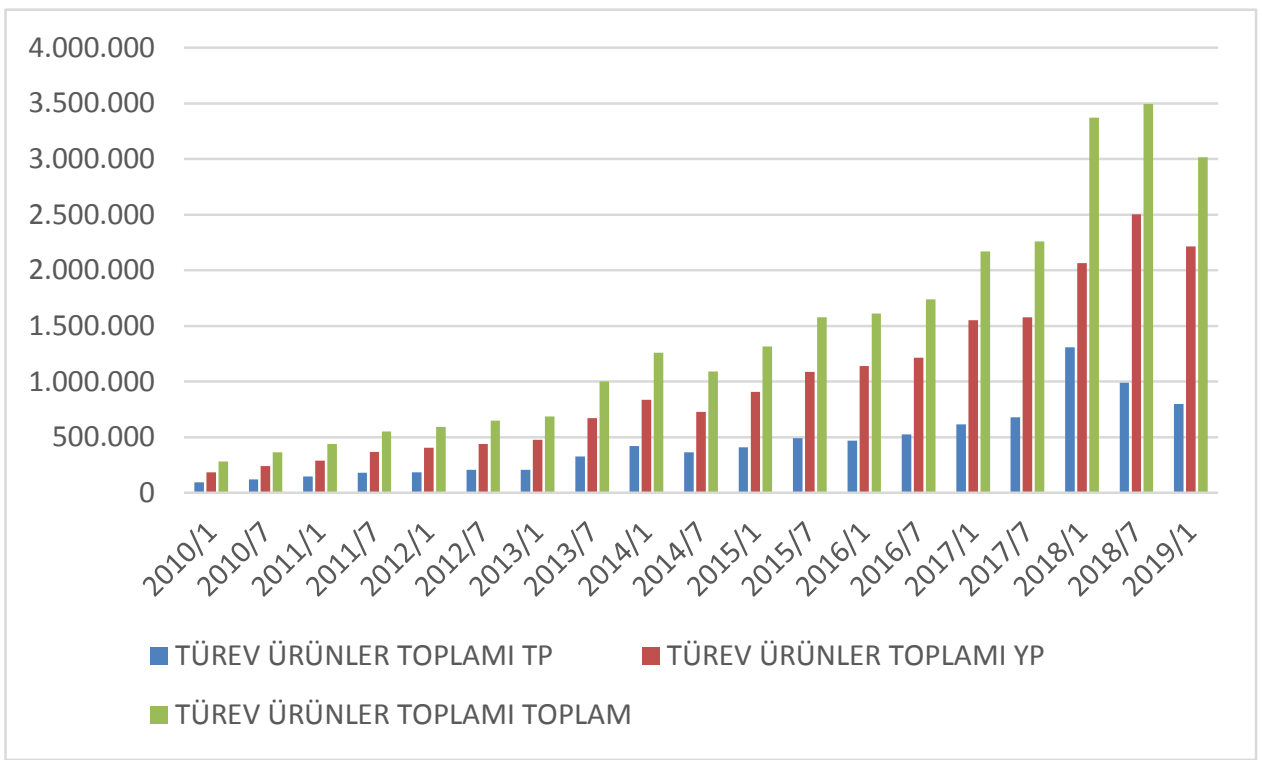

Kaynak: https://www.bddk.org.tr/BultenAylik (BBDK aylık veriler kullanılarak oluşturulmuştur.) 
Bankaların türev ürün kullanımının ana nedenleri arasında; borçlanma kapasitesini ve likidite düzeyini artırmak, borçlanma maliyetlerini düşürmek, mali piyasalardaki volatiliteyi azaltmak gibi nedenleri sıralayabilmek mümkündür. Türev ürünlerin bankacılık sektörüne sağladığı en büyük avantaj, geleceğe yönelik belirsizlikleri ortadan kaldırmaları ve bankacılık faaliyetlerinin sürekliliğini sağlamalarıdır

Bankacılık sektöründe türev ürünlerin kullanımında temel amaç işletmenin ihtiyaç duyduğu nakit akışlarının zamanında sağlanmasıyla işletme değerini yani yatırımcıların hisse senedi değerlerini maksimize etmesini sağlamaktır. Türev ürünler aslında bankaların sermaye yapıları üzerinde bir gider yaratmaktan ziyade gelecekle ilgili belirsizliği azaltarak sermaye yapısı üzerinde daha etkin ve verimli bir yapı sağlamaktadır. Literatürde bankaların türev ürünlerin kullanımıyla bankaların değeri üzerinde etkisini ortaya koyan birçok çalışma yapılmıştır.

Bankalar mevcut döviz pozisyonları sonucunda kurdaki değişimden ve kurdaki volatilite hareketlerinden etkilenmekte ve bunun sonucunda kur riskine maruz kalmaktadırlar. Özellikle Türk bankacılık sektörünün döviz pozisyonlarına bakıldığında, genellikle bilanço içi açık pozisyonlar çalıştı̆̆ görülmekte ve bu pozisyon açığın temel nedeni özel ve yabancı bankaların pozisyonundan ve döviz tevdiat hesapları ile sendikasyon kredisi yoluyla ya da bir başka yolla sağlanan fonların bir kısmının swap işlemleriyle TL'ye çevrilerek plasman yapılmasından kaynaklanmaktadır. Burada mevcut açık pozisyon türev ürünler ile oluşturulmuş bilanço dışı fazla yoluyla dengelenmektedir. $\mathrm{Bu}$ sayede net pozisyon genellikle hem pozitif hem de negatif tarafta sifira yakın bir seviyede dalgalanmaktadır.

\section{Türk Bankacılık Sektöründe Döviz Swap Kullanımı}

Döviz swapı aynı zamanda para swapı olarak ta bilinmektedir. Döviz swapı, iki taraf arasında belirlenen tutardaki bir paranın başka bir para ile değiştirilmesi ve belirli bir süre sonunda değiştirilen anaparaların geri verilmesini içeren kontrat türü olarak ifade edilebilir. Döviz swapında hem anapara hem de faiz ödemeleri de el değiştirmektedir (Kolb \& Overdahl, 2002). Sözleşme sonunda ise ana paralar karşı1ıklı olarak iade edilmektedir. Bunun yanında her iki taraf da borcunu ödeyecek ve ilgili tutarı karşı taraftan elde edecektir. Döviz swapında bankalar sözleşme sonunda geçerli kuru bildikleri için döviz riskine karşı pozisyon alabilmektedirler (Ersan, 1997).

Bankalar döviz swap işlemlerini yaparken her iki taraf açısından risklerin hedge etme olanağı sağlamasına rağmen yapılan işlemden doğan bir takım riskler ortaya çıkmaktadır. Özellikle döviz swap işlemlerinde kur riski en çok karşılaşılan risk türüdür. Döviz swapında işlemler bankalar arasında farklı para birimi cinsinden ödemeler el değiştirmektedir. Burada ortaya çıkan kur riski ilgili para birimlerinin birbirleri karşısında değer kaybetmesi ya da kazanması sonucunda ortaya çıkmaktadır.

Türk bankacılık sektörü bilanço dışı işlemlerinin en büyük kullanımın swap işlemlerinden kaynaklanmaktadır. Özellikle swap işleminde para değişim hem sözleşme anında hem de vade bitiminde yapıldığında Türk bankacılık sektörünün bilanço içi ve dışı pozisyonlarda belirleyici olmaktadır. Örneğin herhangi bir swap işleminde döviz karşıllğında TL verilmesi sonucunda bilanço içinde fazla pozisyona, vade günü döviz karşılığında TL alınması sonucunda bilanço dışı açık pozisyona neden olunmaktadır. Bu durum tersi durumda da gerçekleşebileceği gibi, bu tür kullanımlar özellikle bankacılık sektöründe faiz ve kur üzerinde müdahale yapabilme imkanı sağlayabilmektedir. TCMB ve Bankaların swap işlemi ile yabancı yatırımcılara dolar karşılığı TL aktarmaları piyasadaki TL miktarını azaltırken döviz miktarı artar. Yurt içinde TL karşılığ dolar alınışı, yani dolara olan talep artışı TL/\$ paritesini olumsuz etkiler, dolar kuru TL karşısında değer kazanır. Yani burada bir paradoks vardır. Swap işlemleri ile döviz likidite sorunu çözülürken, ödünç verilen TL'nin tekrar dövize yönlenmesi pariteyi olumsuz etkiler. $\mathrm{Bu}$ durumda TCMB ve BDDK eğer pariteyi önemsiyorlarsa yabancılarla yapılacak swap miktarın sınır getirirler (Yılgör, 2019). 
Türk bankacılık sektörünün bilanço dışında taşıdığı fazla pozisyonun \%90'nı swap işlemlerden kaynaklamakta ve bu durum TL karşılığı döviz swap işlem hacminin, döviz karşılığı alın TL swap işlem hacminden fazla olmasında kaynaklanmaktadır.

Grafik 5: 2010-2018 Yılları Arası Türk Bankacıllk Sektörü Para Swapı İşlem Hacminin Para Birimi İtibarıla Gelişimi (Milyon \$)

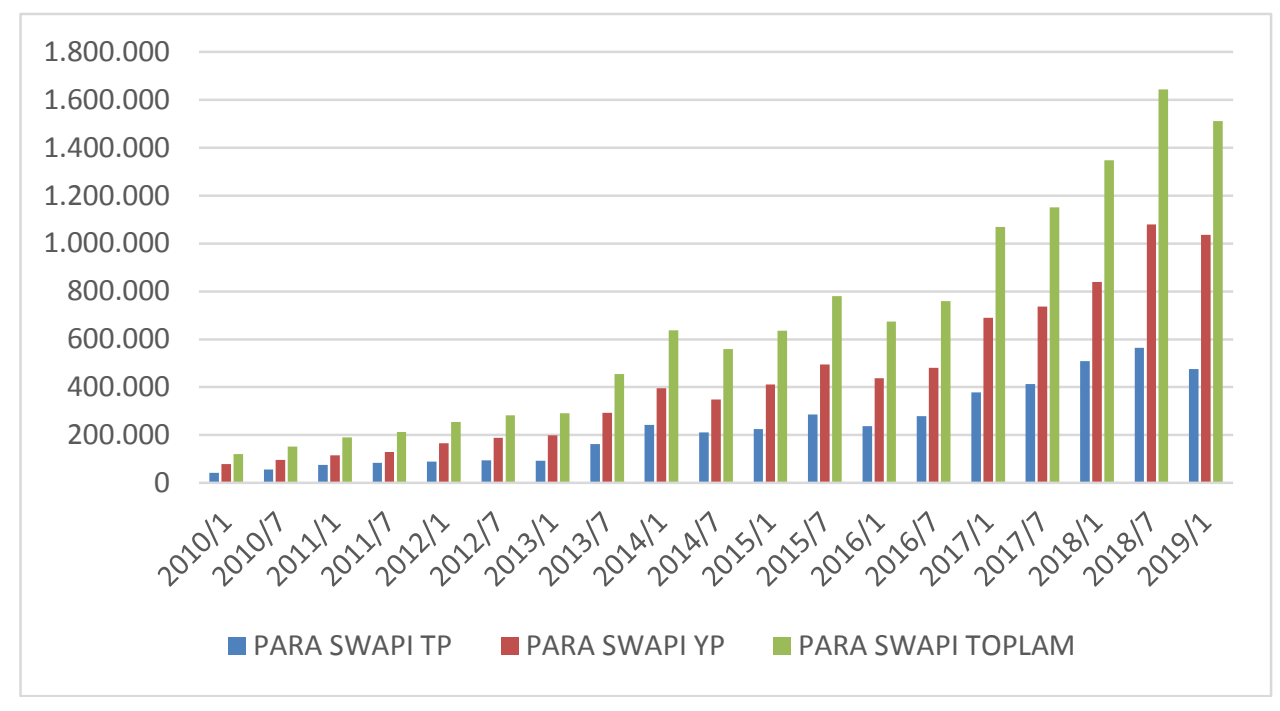

Grafik 5’te 2010-2019 Yılları Arası Türk Bankacılık Sektörü Para Swapı İşlem Hacminin Para Birimi İtibarıyla Gelişimine bakıldığında yıllar itibariyle yabancı para (YP) swapının arttığı, bunun yanında Türk parası(TP) swapı da artmasına karşın, yabancı para swap tutarının altında kalmıştır.

\section{Literatür}

Bankacılık sektörü ile ilgili olarak swap işlemleri ile farklı parametreler arasında yapılan birçok çalışma yapılmış olup, yapılan çalışmalar Tablo 1'de yer almaktadır.

Tablo 1: Literatür Çalışmaları

\begin{tabular}{|c|c|c|c|}
\hline \multirow{2}{*}{ Çalışma } & \multicolumn{2}{|l|}{ Değişkenler } & \multirow{2}{*}{ Sonuç } \\
\hline & Bağımlı & Bağımsız & \\
\hline $\begin{array}{l}\text { Kim ve } \\
\text { Koppenhaver } \\
(1992)\end{array}$ & $\begin{array}{l}\text { Türev Ürün } \\
\text { kullanımı }\end{array}$ & $\begin{array}{l}\text { Faiz oranı riski, sermaye } \\
\text { yapısı }\end{array}$ & $\begin{array}{l}\text { Çalışmada türev ürün kullanımı ile faiz } \\
\text { oranı riski arasında pozitif yönlü bir ilişki, } \\
\text { aktif büyüklüğü ve sermaye yapısı daha } \\
\text { sağlam bankaların türev ürün kullanımına } \\
\text { daha çok başvurdukları gözlemlenmiştir. }\end{array}$ \\
\hline $\begin{array}{l}\text { Bailey ve Chan } \\
\text { (1993) }\end{array}$ & $\begin{array}{l}\text { Türev Ürün } \\
\text { kullanımı }\end{array}$ & $\begin{array}{l}\text { Enflasyon, faiz oran1, kur, } \\
\text { GSMH }\end{array}$ & $\begin{array}{l}\text { Emtiaya dayalı türev ürün piyasalarının } \\
\text { değişen risk primi ve makroekonomik } \\
\text { parametrelerden etkilendiği sonucuna } \\
\text { ulaşmışlardır. }\end{array}$ \\
\hline $\begin{array}{l}\text { Ederington ve } \\
\text { Lee (1993) }\end{array}$ & $\begin{array}{l}\text { Türev Ürün } \\
\text { kullanımı }\end{array}$ & Enflasyon, istihdam, GSMH & $\begin{array}{l}\text { Faize duyarlı türev ürünlerin enflasyona } \\
\text { ilişkin haberlere, dövize dayalı türev ürün } \\
\text { kullanımı ise istihdam ve GSMH ilişkin } \\
\text { haberlere duyarlı oldukları tespit edilmiştir. }\end{array}$ \\
\hline
\end{tabular}




\begin{tabular}{|c|c|c|c|}
\hline $\begin{array}{l}\text { Sinkey ve } \\
\text { Carter } \\
(2001)\end{array}$ & $\begin{array}{l}\text { Türev Ürün } \\
\text { kullanımı }\end{array}$ & $\begin{array}{l}\text { Toplam Aktifler, Öz Kaynak } \\
\text { Tutarı, Net Faiz Geliri, } \\
\text { Likit Aktifler, Kar Payı } \\
\text { Tutarı, Tahviller, Likidite } \\
\text { oranı } \\
\text { Bankanın holding olma } \\
\text { durumu, Takipteki } \\
\text { Krediler/Toplam Krediler }\end{array}$ & $\begin{array}{l}\text { Çalışmada faiz oranı riskine bağlı olarak } \\
\text { faize dayalı türev ürün kullanımın arttığı } \\
\text { tespit etmişlerdir. Buna ilaveten bankaların } \\
\text { özellikle sermaye yapısı güçlü olanların } \\
\text { faiz oranı swapına daha çok başvurdukları } \\
\text { görülmüşsür. Çalışmada banka aktif } \\
\text { büyüklüğ̈u ile türev ürün kullanımı } \\
\text { arasında herhangi bir ilişki tespit } \\
\text { edilememiștir. }\end{array}$ \\
\hline $\begin{array}{l}\text { Thakral ve } \\
\text { Kumar (2007) }\end{array}$ & $\begin{array}{l}\text { Türev Ürün } \\
\text { kullanımı }\end{array}$ & $\begin{array}{l}\text { Faiz oranı riski, Borsa } \\
\text { endeksi }\end{array}$ & $\begin{array}{l}\text { Bankların faize dayalı swap kullanımı ile } \\
\text { faiz oranı volatilitesi arasında negatif bir } \\
\text { ilişki tespitine karşın swap kullanımı ile } \\
\text { borsa endeksi arasında anlamlı bir ilişki } \\
\text { tespit edilmemiştir. }\end{array}$ \\
\hline $\begin{array}{l}\text { Thirumathi } \\
\text { (2009) }\end{array}$ & $\begin{array}{l}\text { Türev Ürün } \\
\text { kullanımı }\end{array}$ & $\begin{array}{l}\text { Toplam Aktifler, Toplam } \\
\text { Kredi/ Toplam Aktifler, } \\
\text { Takipteki Krediler/Toplam } \\
\text { Krediler, Net Faiz Geliri, } \\
\text { Kar, Sermaye }\end{array}$ & $\begin{array}{l}\text { Bankaların kredi oranları ve net faiz geliri } \\
\text { arasında anlamlı bir ilişki bulunmuş olup, } \\
\text { diğer değişkenler arasında anlamlı bir ilişki } \\
\text { tespit edilememiştir. }\end{array}$ \\
\hline $\begin{array}{l}\text { Hassan ve } \\
\text { Khasawneh } \\
\text { (2009) }\end{array}$ & $\begin{array}{l}\text { Türev Ürün } \\
\text { kullanımı }\end{array}$ & GSYH, Faiz oranı, enflasyon, & $\begin{array}{l}\text { Çalışma sonucunda reel GSYH ve büyüme } \\
\text { değişkenleri ile opsiyon kullanımı; forward } \\
\text { kullanımı ve faiz oranları; enflasyon ve } \\
\text { swap ve forward kullanımı arasında negatif } \\
\text { bir ilişskinin mevcudiyeti tespit etmişlerdir. } \\
\text { Buna karşın diğer makroekonomik } \\
\text { değişkenler arasında anlamlı bir ilişkininin } \\
\text { mevcudiyeti bulunamamıştır. }\end{array}$ \\
\hline $\begin{array}{l}\text { Moles vd. } \\
\text { (2010) }\end{array}$ & $\begin{array}{l}\text { Türev Ürün } \\
\text { kullanımı }\end{array}$ & $\begin{array}{l}\text { Likidite Oranı, Dağıtılan Kar } \\
\text { Oranı, Gelir, } \\
\text { Maliyet, Zarar, Faaliyet Dışı } \\
\text { Gelirler, Takipteki Krediler, } \\
\text { Öz Sermaye Getiri Oranı, } \\
\text { Toplam Aktifler, Net Faiz } \\
\text { Marjı }\end{array}$ & $\begin{array}{l}\text { Çalışmada banka aktif büyüklüğü ile türev } \\
\text { ürün kullanımı arasında doğru orantılı bir } \\
\text { ilişsk mevcudiyetine karşın diğer } \\
\text { değişkenler arasında anlamlı herhangi bir } \\
\text { ilişki bulunamamıştır. }\end{array}$ \\
\hline $\begin{array}{l}\text { Srivastava ve } \\
\text { Srivastava } \\
\text { (2010) }\end{array}$ & $\begin{array}{l}\text { Türev Ürün } \\
\text { kullanımı }\end{array}$ & $\begin{array}{l}\text { Toplam Aktifler, Toplam } \\
\text { Kredi, Toplam Mevduat, } \\
\text { Sermaye, Sermayenin Getiri } \\
\text { Oran1, Aktif Getiri Oran1, } \\
\text { Net Faiz Marj1, Takipteki } \\
\text { Kredi Oranı } \\
\end{array}$ & $\begin{array}{l}\text { Türev ürün kullanımı ile banka aktif } \\
\text { büyüklüğü arasında ters yönlü bir iliş̧ki } \\
\text { mevcudiyetine karşın diğer değişkenler } \\
\text { arasında anlamlı herhangi bir ilişki tespit } \\
\text { edememişlerdir. }\end{array}$ \\
\hline $\begin{array}{l}\text { Shiu ve Moles } \\
\text { (2010) }\end{array}$ & Tayvan & Piyasa, Faiz oranı, Kur Riski & $\begin{array}{l}\text { Türev ürün kullanımı ile Piyasa Riski, Faiz } \\
\text { oranı Riski, Kur riski doğru orantılı bir } \\
\text { ilişki bulunamamıştır. }\end{array}$ \\
\hline $\begin{array}{l}\text { Anbar ve Alper } \\
\text { (2011) }\end{array}$ & $\begin{array}{l}\text { Türev Ürün } \\
\text { kullanımı }\end{array}$ & $\begin{array}{l}\text { Toplam Aktifler, Aktif } \\
\text { Karlılı̆̆ı, Öz Sermaye } \\
\text { Karlılı̆̆ı, } \\
\text { Net Faiz Marjı, Likidite } \\
\text { Oranı, } \\
\text { Toplam Kredi/Toplam Aktif, } \\
\text { Takipteki Krediler, } \\
\text { Karşılıklar, Faiz Oranı, } \\
\text { Ekonomik Büyüme, } \\
\text { Enflasyon }\end{array}$ & $\begin{array}{l}\text { Çalışmada türev ürün kullanımı ile faiz } \\
\text { oranı arasında ters yönlü, ekonomik } \\
\text { büyüme ve enflasyon arasında herhangi bir } \\
\text { ilişki bulunamamıştır. }\end{array}$ \\
\hline
\end{tabular}




\begin{tabular}{|c|c|c|c|}
\hline Elder vd. (2012) & Amerika & $\begin{array}{l}\text { Altın, Gümüş ve Bakır işlem } \\
\text { hacimleri ve volatiliteleri }\end{array}$ & $\begin{array}{l}\text { Çalışmada ekonomide yaşanan } \\
\text { beklenmedik gelişmelerin altın ve gümüşe } \\
\text { dayalı türev ürünler işlemlerini negatif } \\
\text { yönde, buna karşın bakıra dayalı dayalı } \\
\text { türev ürünler işlemlerini pozitif yönde } \\
\text { etkilediği tespit etmişlerdir. }\end{array}$ \\
\hline $\begin{array}{l}\text { Straathof ve } \\
\text { Calio (2012) }\end{array}$ & $\begin{array}{l}\text { OECD de yer } \\
\text { alan } 50 \text { Ülke }\end{array}$ & $\begin{array}{l}\text { GSYIH, Finansal Gelişmeler, } \\
\text { Döviz Kurları }\end{array}$ & $\begin{array}{l}\text { Çalışmada dövize dayalı türev ürün } \\
\text { kullanımının kur volatilitesinden daha az } \\
\text { etkilendikleri buna ilaveten türev ürün } \\
\text { kullanımı ve kur volatilitesi arasında } \\
\text { pozitif bir iliş̧ki tespit etmişlerdir. }\end{array}$ \\
\hline Shiu vd. (2012) & $\begin{array}{l}\text { Türev Ürün } \\
\text { kullanımı, } \\
\text { Tayvan }\end{array}$ & $\begin{array}{l}\text { Firma Büyüklüğ̈̈, Mali } \\
\text { sıkıntı, Varlıkların Faiz oranı } \\
\text { riski, } \\
\text { Yükümlülüklerin Faiz oranı } \\
\text { riski, Büyüme Fırsatları, } \\
\text { Reasürans, Kurumsal, } \\
\text { sahiplik, yönetimsel sahiplik, } \\
\text { YP Toplam aktifler ile } \\
\text { ölçeklendirilen toplam } \\
\text { yabancı yatırım tutarı, } \\
\text { NIM Net gelir neticesinde } \\
\text { ölçeklendirilen net faiz marjı, } \\
\text { Yatırım bağlantılı olarak } \\
\text { temsil edilen temel varlıkların } \\
\text { INV Değeri brüt yazılı } \\
\text { primlerle ertelenen sigorta } \\
\text { [yaşam sektörü için], Talep } \\
\text { ödemelerinin } \\
\text { konsantrasyonunu yansıtan } \\
\text { HERFC Herfindahl endeksi, } \\
\text { IR Net Yatırım gelirinin } \\
\text { toplam varlıklara bölünmesi } \\
\text { [yaşam sektörü için] }\end{array}$ & $\begin{array}{l}\text { Türev ürün kullanımı ile faiz oranı ve kur } \\
\text { riski arasında pozitif bir ilişki tespitine } \\
\text { karşın daha fazla likiditeye sahip } \\
\text { bankaların daha az türev ürün kullanımına } \\
\text { başvurduklarını tespit etmişlerdir. Buna } \\
\text { ilaveten aktif büyüklüğ̈̈ büyük olan } \\
\text { bankaların daha çok türev ürün } \\
\text { kullanımına başvurdukları sonucuna } \\
\text { ulaşmışlardır. }\end{array}$ \\
\hline $\begin{array}{l}\text { Özgümüs vd. } \\
\text { (2013) }\end{array}$ & $\begin{array}{l}\text { Türev Ürün } \\
\text { kullanımı, } \\
\text { Türkiye }\end{array}$ & $\begin{array}{l}\text { Altın, BA/GSYIHH, büyüme, } \\
\text { CA/GSYİH, enflasyon, faiz, } \\
\text { ihracat, ithalat ve para arzı, } \\
\text { SveP500 } \\
\text { *BA=Bütçe Açı̆̆ } \\
\text { *CA=Cari İşlemler Açığ } 1\end{array}$ & $\begin{array}{l}\text { CA/GSYİH yükselmesi ve altın fiyatlarının } \\
\text { artması dolara dayalı türev ürün } \\
\text { kullanımını arttırdığı; altın fiyatlarının, reel } \\
\text { olarak para arzının ve SveP500 getirisinin } \\
\text { artması Euro dayalı türev ürün kullanımını } \\
\text { arttırdığı; para arzının artması ve } \\
\text { enflasyonun düşmesi İMKB } 100 \text { vadeli } \\
\text { işlem sözleşme kullanımının arttırdığını } \\
\text { tespit etmişlerdir. }\end{array}$ \\
\hline $\begin{array}{l}\text { Kohlscheen ve } \\
\text { Andrade (2013) }\end{array}$ & $\begin{array}{l}\text { Türev Ürün } \\
\text { kullanımı, } \\
\text { Brezilya } \\
\end{array}$ & BRL / USD spot döviz kuru. & $\begin{array}{l}\text { Türev ürün kullanımı ile merkez bankası } \\
\text { rezervleri arasında negatif bir ilişsi tespit } \\
\text { etmişlerdir. }\end{array}$ \\
\hline $\begin{array}{l}\text { Oktar ve Yüksel } \\
\text { (2015) }\end{array}$ & $\begin{array}{l}\text { Türev Ürün } \\
\text { kullanımı, } \\
\text { Türkiye }\end{array}$ & $\begin{array}{l}\text { Aktif Büyüklüğü, Büyüme } \\
\text { Oranı,Enflasyon, Faiz Oranı } \\
\text {,Krediler ,Likidite } \\
\text { Oranı,Mevduat, Net Faiz } \\
\text { Marjı,Takipteki Krediler } \\
\text {,Özel Karş111klar,Sermaye } \\
\text {,Aktif Karlılığı, Öz Sermaye } \\
\text { Karlılık Oranı }\end{array}$ & $\begin{array}{l}\text { Bankalar tarafindan ayrılan özel } \\
\text { karşılıkların ve takipteki kredileri } \\
\text { bankaların türev ürün kullanımı konusunda } \\
\text { etkili olduğu, Buna karşın, diğer } 12 \text { adet } \\
\text { bağımsız değişkenin türev ürün } \\
\text { kullanımını etkilediğine yönelik bir sonuç } \\
\text { bulunamadıkları tespit edilmiştir. }\end{array}$ \\
\hline
\end{tabular}




\begin{tabular}{|l|l|l|l|}
\hline Khan (2016) & $\begin{array}{l}\text { Türev Ürün } \\
\text { kullanımı, } \\
\text { Pakistan }\end{array}$ & $\begin{array}{l}\text { Faiz oranı swapı, Banka } \\
\text { büyüklüğü, likidite ve risk } \\
\text { yönetimi uygulamaları }\end{array}$ & $\begin{array}{l}\text { Bankalar tarafindan faiz oranı swap } \\
\text { kullanımın banka büyüklüğ̈ ile anlamlı bir } \\
\text { ilişkisi olmadığı, riskten korunma amaçlı } \\
\text { olarak döviz swap kullanımının, bankalara } \\
\text { kiyaslama avantajı sunduğu ve likit } \\
\text { bankaların hem kredi riski hem de faiz } \\
\text { oranı risklerinden korunma amaçlı olarak } \\
\text { avantaj sağladıkları görülmüştür. }\end{array}$ \\
\hline
\end{tabular}

\section{Veri ve Metodoloji}

Bankaların türev ürün kullanımını etkileyen makroekonomik değişkenlerin belirlenmesi, bankacılık sektörü türev ürün kullanım dinamiklerinin anlaşılabilirliği açısından önem arz etmektedir. $\mathrm{Bu}$ açından Türk bankacılık sektöründe türev ürün kullanımının büyük kısmını oluşturan döviz swapları kullanımına etki eden makroekonomik değişkenlerin belirlenmesine yönelik analizler yapilacaktır.

\subsection{Veri}

Türk bankacılık sektöründe kullanılan döviz swap kullanımı ortaya koyan çalışmada 20102018 dönemleri esas alınmıştır. Çalışmaya 2010 yılında itibaren başlanılmasının ana nedeni bu dönemden itibaren döviz swap işlemlerinin kullanımın daha etkin bir hacimde kullanılmaya başlanılmasıdır. Çalışmada bağımlı değişken olarak bankacılık sektöründe kullanılan döviz swap miktarı kullanılmıştır. Bağımsız değişkenler olarak kullanılan makroekonomik değişkenlerin belirlenmesinde literatür çalışmalarının yanı sıra döviz swap miktarını etkileyebilecek değişkenler dikkate alınmıştır. Yapılan literatür çalışmaları sonucunda bağımsız değişkenler olarak piyasa riski, faiz oranı, kur volatilitesi, bilanço dışı riskler, enflasyon ve bankaların TL mevduatları olarak belirlenmiştir. Araştırmada kullanılan veriler aylık frekans olarak oluşturulmuştur. İlgili veriler TCBM, Bloomberg, BBDK ve TBB'den sağlanmıştır.

Çalışmada faiz oranı temsil edilebilmesi açısından nominal faiz oranının ele alınması daha önce yapılan literatür çalışmalarıyla desteklenmektedir. Özellikle faiz oranlarının yüksek ve volatil olduğu durumlarda bankaların riskten korunma amaçlı olarak türev ürün kullanımına başvurmalarının yanında belirsizliğin baş gösterdiği ortamlarda ayrıca risk üstlenmemek için türev ürün kullanımına başvurmayabilmektedirler. (Hassan ve Khasawneh 2009: 11). Piyasada faiz oranları ile türev ürün kullanımı arasında beklenen görüşü genellikle aynı yönlü bir ilişkinin olabileceği ifade edilmektedir. Buna neden olan unsurun özellikle faiz oranlarında yaşanan artış risk primini arttırdığından bankaların döviz swap kullanımını arttırdıkları beklentisi çalışmada ortaya konmaya çalışılacaktır.

Çalışmada bağımsız değişken olarak ela alınan kur volatilitesini temsilen \$/TL kurunun aylık volatilite değerleri alınmıştır. Bu açıdan \$/TL kurunun türev ürün kullanımını ifade etmesi açısından kur volatilitesi değişkeninin kullanılabileceği literatür çalışmalarıyla desteklenmektedir. $\mathrm{Bu}$ değişkenler arasında ki ilişkinin de tıpkı faiz oranı riskinde de ifade dildiği üzere, kur volatilitesinde ki artış bankaların maruz kalacakları kur riski arttıracağından, kur volatilitesinin bağımlı değişken ile ilişki derecesinin pozitif çıkması beklenmektedir.

Bağımsız değişkenden bilanço dışı riskleri ifade etmesi bakımından bilanço sektörünün maruz kaldığ1 bilanço dışı risklerin sektörün toplam aktiflerine oranı kullanılmıştır. Bilanço dışı riskler, bankaların şarta bağlı varlık ve yükümlülüklerinden kaynaklanan riskleri ifade etmektedir. Türev araçlardaki pozisyonlar bilanço dışında takip edilmektedir Bir diğer bağımsız değişkenden olan piyasa riskini ifade etmesi bakımından bankacılık sektörünün sermaye yeterliliğinin tespitinde kullanılan piyasa riskine esas tutar değeri kullanılmıştır. Araştırma kullanılan enflasyon değişkenini ifade etmesi bakımından TÜFE(temsilen tüketici fiyat endeksi) değerleri kullanılmıştır. Döviz swapı kullanımında 
etkili olabileceği düşünülen enflasyon değişkeninin kullanımı literatür çalışmalarıyla tutarlılık göstermektedir.

Tablo 2: Araştırmada Kullanılan Değişkenler

\begin{tabular}{|l|l|l|}
\hline & Değişkenler & Kod \\
\hline 1 & DSM & Döviz Swap Miktarı \\
\hline 2 & ENF & Enflasyon \\
\hline 3 & FA & Faiz \\
\hline 4 & KV & Kur Volatilitesi \\
\hline 5 & BDR & Bilanço Dişı Riskler \\
\hline 6 & BTLM & Bankalarda ki TL Mevduatı 1 \\
\hline 7 & PR & Piyasa Riski \\
\hline
\end{tabular}

\subsection{Metodoloji}

Modelde Türk bankalarının döviz swapları üzerinde açıklama derecesi olduğu düşünülen makroekonomik değişkenler analize dahil edilmiş olup, ilgili model havuzlanmış regresyon modeli çerçevesinde analiz edilmiştir. Bu amaçla kurulan model denklemi (1) aşağıda yer almaktadır.

$$
\mathrm{DSWAP}=\beta_{1} * \mathrm{ENF}+\beta_{2} * \mathrm{FA}+\beta_{3} * \mathrm{KV}+\beta_{4} * \mathrm{BDR}+\beta_{4} * \mathrm{BTLM}+\beta_{5} * \mathrm{PR}+\varepsilon \mathrm{i}, \mathrm{t}
$$

Günümüzde panel veri analizinin en aktif ve en yenilikçi hale gelmesinin nedenlerinin başında özellikle tahmin yöntemleri ve teorik altyapısının gelișiminden kaynaklanmaktadır (Greene, 2003).Bunun yanında panel veri analizinin iki boyutlu bir analiz türü olması bünyesinde birçok avantaji bulundurmaktadır. Bu sayede yapısında hem yatay hem de zaman kesit verilerini bir araya getirmesinden dolayı, daha fazla veriyle daha yüksek serbestlik derecesi ile tahmin yapmayı sağlamaktadır. $\mathrm{Bu}$ sayede gözlem sayısı arttığı zaman çoklu doğrusal bağlantı sorunu elemine edilmektedir (Hsiao, 2002). Bunun yanında panel veri analizi yatay kesitlere özgü heterojenliği göz önüne alması, kapsamlı modelleri test edebilmesi, model belirleme sorunu nedeniyle ortaya çıan kusurlara çözüm getiren yöntemleri bünyesinde bulundurması ve çoklu doğrusal bağlantıları azaltması panel veri analizi yönteminin sağladığı avantajlar arasında öne çıkan kısımlarıdır.

Panel veri analizi modelleri, yatay kesit bağımlılı̆̆ barındırmadığ 1 varsayımı, birimler arasında ve birim içinde homoskedastik (sabit varyansl1) olduğu ve birim içinde otokorelasyon olmadığı varsayımlarına dayanmaktadır. $\mathrm{Bu}$ varsayımların gerçekleşmesi koşuluyla panel veri analizine uygun tahmin yöntemlerinden biri seçilebilecektir.

Panel veri analizi sabit, eğim ve hata terime ilişkin varsayımlara bağlı olarak farklı şekillerde modellenebilmektedir. Panel veri analizi, Havuzlanmış En Küçük Kareler (HEKK - Pooled OLS, Klasik Model), Sabit Etkiler (Fixed Effects) ve Rassal Etkiler (Random Effects) yaklaşımlarından biri kullanılarak tahmin edilmektedir (Wooldridge, 2009). Birim ve zaman etkilerinin homojen olduğu durumda, hata terimi her iki etkiyi de içermediği durumda, etkin ve tutarlı tahminciler veren HEKK Yöntemi, eğim parametrelerinin tüm yatay kesit birimler için aynı, sabit parametrenin birimler arasında farklılaştığı (birim etki içerdiği) durumda Sabit Etkiler (SE) yaklaşımı ve eğim parametreleri yatay kesitler arasında değişiyorsa ve örnekteki birimler rassal olarak seçildiği durumda ise Rassal Etkiler (RE) yaklaşımı kullanılmaktadır (Önder, 2017). Çalışma döviz swapları ile diğer değişkenler arasındaki ilişkinin stabil olduğu varsayımıyla en uygun yöntemin Havuzlanmış En Küçük Kareler (HEKK - Pooled OLS, Klasik Model) yöntemi tercih edilmiştir.

Panel veri analizi yönteminde yatay kesit ve zaman serilerinin birlikte kullanımı çeşitli problemleri beraberinde getirmektedir. Bundan dolayı yatay kesit bağımlılı̆̆ (hata teriminin birimler arasında korelasyon) ve zaman serilerinde karşılaşılan birim kök varlığı problemleri göz önünde 
bulundurulmalıdır (Bilman, 2014). Yatay kesit bağımlılı̆̆ için zaman serilerinde karşılaşılan birim kök varlığı problemi için Im, Peseran, Shin (2003) birim kök testi kullanılacaktır.

Panel veri analizi çalmalarında birim kök testleri; bireysel birim kök testleri Im, Peseran, Shin (2003)(IPS) ile Levin, Lin, Chu (2002) (LLC) ortak birim kök testleri ile sınanmaktadır. Bu çalışmada her iki testten faydalanılmıştır. ifade edilebilir.

Im, Peseran, Shin (2003) testini hem sabit hem de trendli olarak aşağıda yer alan denklemle

$$
\Delta \mathrm{y}_{\mathrm{it}}=\mu_{\mathrm{i}}+\beta_{\mathrm{i}} \mathrm{y}_{\mathrm{i}, \mathrm{t}-1}+\sum_{\mathrm{k}=1}^{\mathrm{p}_{\mathrm{i}}} \theta_{\mathrm{i}, \mathrm{k}} \Delta \mathrm{y}_{\mathrm{i}, \mathrm{t}-\mathrm{k}}+\gamma_{\mathrm{i}} \mathrm{t}+\varepsilon_{\mathrm{it}}
$$

İlgili testte $\mathrm{H}_{\mathrm{O}}$ hipotezi bütün yatay kesit birimleri (i) için $\beta_{\mathrm{i}}=0$ şeklinde, $\mathrm{H}_{1}$ hipotezi gerekli kritik değerler ise en az bir yatay kesit birimi $\left(\beta_{\mathrm{i}}<0\right)$ şeklinde oluşturulur. Eğer $\mathrm{H}_{\mathrm{O}}$ hipotezi reddedilirse serilerinden en birinin durağan olduğu sonucuna ulaşılır ve bu test için ilgili kritik değerler Im, Peseran, Shin (2003) tablosundan alınmaktadır. İlgili denklemden trend çıkarıldığı zaman ise sabit modele ulaşılmaktadır.

Levin, Lin, Chu (2002) (LLC) ise ortak bir birim kök oluşturulması gerektiğini, bireysel birim kök testlerinin ise alternatif hipotezlere karşı etkisinin zayıf kaldığını ifade etmektedir. Bir başka ifadeyle Levin, Lin, Chu (2002) (LLC) her bir yatay kesit birimi için bireysel birim kök testlerine nazaran daha güçlü ve daha sağlıklı sonuçlar veren ortak bir panel birim kök testi önermektedir. Levin, Lin, Chu (2002) birim kök testi istatistiklerindeki regresyon tanımlamalarının altında asimptotik varyans ve ortalamalarının değiştiğini gözlemlemişlerdir (Levin, 2002). Levin, Lin, Chu aşağıda yer alan denklemle ifade edilebilir (BALTAGI, 2005).

$$
\Delta y_{i t}=\rho_{i} y_{i, t-1}+\sum_{\mathrm{L}=1}^{p_{i}} \theta_{i, L} \Delta y_{i, t-L+} \alpha_{m i} d_{m t}+\varepsilon_{i t} \quad m=1,2,3
$$

Tablo 3: Im, Peseran, Shin Birim Kök Test Sonuçları

\begin{tabular}{|l|l|l|l|}
\hline Değişkenler & Model & t* istatistiği $^{*}$ Sonuç \\
\hline \multirow{2}{*}{ Enflasyon } & Sabitli & $-7,674^{*}$ & $\mathrm{I}(0)$ \\
& Sabitli-Trendli & $-5.198^{*}$ & $\mathrm{I}(0)$ \\
\hline \multirow{2}{*}{ Faiz } & Sabitli & $-7.123^{*}$ & $\mathrm{I}(0)$ \\
& Sabitli-Trendli & $-7.698^{*}$ & $\mathrm{I}(0)$ \\
\hline \multirow{2}{*}{ Kur Volatilitesi } & Sabitli & $-5,478^{*}$ & $\mathrm{I}(0)$ \\
& Sabitli-Trendli & $-3,167^{*}$ & $\mathrm{I}(0)$ \\
\hline Bilanço Dış1 & Sabitli & $-17,698^{*}$ & $\mathrm{I}(0)$ \\
Riskler & Sabitli-Trendli & $-13,354^{*}$ & $\mathrm{I}(0)$ \\
\hline Bankalarda ki TL & Sabitli & $-13,243^{*}$ & $\mathrm{I}(0)$ \\
Mevduatı & Sabitli-Trendli & $-11,165^{*}$ & $\mathrm{I}(0)$ \\
\hline \multirow{2}{*}{ Piyasa Riski } & Sabitli & $-9,198^{*}$ & $\mathrm{I}(0)$ \\
& Sabitli-Trendli & $-5,591^{*}$ & $\mathrm{I}(0)$ \\
\hline
\end{tabular}

İlgili denklemde $\mathrm{d}_{\mathrm{mt}}$ deterministik değişkenler vektörünü, $\alpha_{\mathrm{mi}}$ ise modelin katsayılar vektörünü ifade etmektedir. $\rho_{\mathrm{i}}$ gecikme uzunluğunu, $\rho_{\max }$ maksimum lag uzunluğunu, $\alpha_{\mathrm{m}}$ parametreleri ve $\varepsilon_{\text {it }}$ hata terimini ifade etmektedir. Levin, Lin, Chu (2002) ilgili modelde testlerini gerçekleştirmek için üç farklı model öngörmektedir. Bu modeller sabit parametresiz, sabit parametreli ve sabit parametreli ve trendli olmak üzere üç farklı modelle oluşturulmaktadır.

$$
\begin{aligned}
& \text { Sabitli Model }=\Delta \mathrm{y}_{\mathrm{it}}=\rho_{\mathrm{i}} \mathrm{y}_{\mathrm{i}, \mathrm{t}-1}+\mathrm{u}_{\mathrm{it}} \\
& \text { Sabitli-Trendli Model }=\Delta \mathrm{y}_{\mathrm{it}}=\alpha_{\mathrm{oi}}+\rho_{\mathrm{i}} \mathrm{y}_{\mathrm{i}, \mathrm{t}-1}+\mathrm{u}_{\mathrm{it}} \\
& \text { Sabitsiz-Trendsiz Model }=\Delta \mathrm{y}_{\mathrm{it}}=\alpha_{\mathrm{oi}}+\alpha_{1 \mathrm{it}}+\rho_{\mathrm{i}} \mathrm{y}_{\mathrm{i}, \mathrm{t}-1}+\mathrm{u}_{\mathrm{it}}
\end{aligned}
$$


Burada $u_{i t}$ hata sürecini ifade etmektedir. Sabitli modelde $H_{0}=p=0$ durumunu $H_{1}: p<0$ durumunu incelemektedir. Sabitli-Trendli model ise $y_{\text {it }}$ serilerinin zaman trendi içermeyen bireysel bir ortalamaya sahip olduğunu yani tüm i durumlarında $\mathrm{H}_{\mathrm{O}}=\mathrm{p}=0 \quad \alpha_{\mathrm{oi}}=0$ ile $\mathrm{H}_{1}: \mathrm{p}<0 \quad \in \mathrm{R}$ olarak kabul edilmektedir. Sabitsiz-Trendsiz modelde ise $y_{i t}$ serilerinin hem zaman trendi hem de bireysel bir ortalamaya sahip olduğunu yani tüm i durumlarında $\mathrm{H}_{\mathrm{O}}=\mathrm{p}=0 \quad \alpha_{1 \mathrm{i}}=0$ ile $\mathrm{H}_{1}$ : $\mathrm{p}<0 \quad \alpha_{1 \mathrm{i}} \in \mathrm{R}$ olarak kabul edilmektedir.

Panel veri regresyon modellerinin temel varsayımlarından biri değişkenlerin durağan bir yapı sergilemesidir. Sahte regresyon sorunun ortadan kaldırılıp her bir değişkenin durağan düzeyleri ile regresyon analizine dahil edilmesi gerekmektedir. Bu çalışmada serilerin durağanlığı Levin Lin ve Chu (LLC) ve Im, Pesaran ve Shin (IPS) birim kök testleri kullanılarak sabitli, sabitli-trendli ve none(sabitsiz-trendsiz) modelleri çerçevesinde $\% 5$ anlamlılık düzeyinde analiz edilmiştir. Im, Pesaran ve Shin (IPS) birim analizde sabitli ve sabitli-trendli olmak üzere iki farklı model analiz edilmiștir. Levin Lin ve Chu (LLC) modelinde ise sabitli, sabitli-trendli ve none(sabitsiz-trendsiz) modelleri olmak üzere üç farklı model analiz edilmiştir.

Tablo 4: Levin, Lin, Chu Birim Kök Test Sonuçları

\begin{tabular}{|l|l|l|l|}
\hline Değişkenler & Model & t* $^{*}$ istatistiği & Sonuç \\
\hline \multirow{3}{*}{ Enflasyon } & Sabitli & $-9,985^{*}$ & $\mathrm{I}(0)$ \\
& Sabitli-Trendli & $-5,126^{*}$ & $\mathrm{I}(0)$ \\
& None & $-3,654^{*}$ & $\mathrm{I}(0)$ \\
\hline \multirow{3}{*}{ Faiz } & Sabitli & $-11.143^{*}$ & $\mathrm{I}(0)$ \\
& Sabitli-Trendli & $-9.543^{*}$ & $\mathrm{I}(0)$ \\
& None & $-8.121^{*}$ & $\mathrm{I}(0)$ \\
\hline \multirow{3}{*}{ Kur Volatilitesi } & Sabitli & $-5,654^{*}$ & $\mathrm{I}(0)$ \\
& Sabitli-Trendli & $-7,123^{*}$ & $\mathrm{I}(0)$ \\
& None & $-11,131^{*}$ & $\mathrm{I}(0)$ \\
\hline \multirow{2}{*}{ Bilanço Dış1 } & Sabitli & $-11,154^{*}$ & $\mathrm{I}(0)$ \\
Riskler & Sabitli-Trendli & $-10,127^{*}$ & $\mathrm{I}(0)$ \\
& None & $-19,987^{*}$ & $\mathrm{I}(0)$ \\
\hline \multirow{2}{*}{ Bankalarda ki TL } & Sabitli & $-13,453^{*}$ & $\mathrm{I}(0)$ \\
Mevduatı & Sabitli-Trendli & $-9,975^{*}$ & $\mathrm{I}(0)$ \\
& None & $-17,765^{*}$ & $\mathrm{I}(0)$ \\
\hline \multirow{3}{*}{ Piyasa Riski } & Sabitli & $-11,123^{*}$ & $\mathrm{I}(0)$ \\
& Sabitli-Trendli & $-5,983^{*}$ & $\mathrm{I}(0)$ \\
& None & $-13,419^{*}$ & $\mathrm{I}(0)$ \\
\hline
\end{tabular}

Parametre tahmini yapılmadan önce, panel veri analiz modelinin belirlenmesi gerekmektedir. $\mathrm{Bu}$ amaçla, modelin belirlenmesi adına, Hausman test istatistiğinden yararlanarak sabit etkiler modeli ya da rassal(tesadüfi) etkiler modeli arasında seçim yapılması gerekmektedir. Panel veri modelinin iki farklı yöntem kullanılmaktadır. Bunlar sabit etkiler ve rassal etkiler modelleridir. Sabit etkiler modeli, birimler arasında bireysel farklılıkların, sabit terimde yer alan farklılıklarla ortaya çıkarılabileceğini varsaymaktadır. Bu sayede her bir değişken, zaman göre değişmeyen bir sabit terime yani model dışında bırakılan bağımsız değişkenlerin etkilerini gösterecektir. Rassal etkiler modeli ise sabit etkiler modelin tüm varsayımlarının yanında bireysel ve zaman etkilerinin bağımsız değişkenler ile ilişkili olmadığını kabul etmektedir. Tablo 5'ten görüldüğü üzere Hausman testi sonucuna göre olasılık değerinin 0.05 ten büyük olduğu için Havuzlanmış Modele uygun olmadığg ve modelin tutarlı ve etkin olabilmesi için rassal etkiler tahminleyicisinin kullanılarak tahmin edilmesi gerektiği sonucuna ulaşılmıştır.

Durbin - Watson testi kurulan modellerde sabit terim bulunması ve bağımsız değişkenler arasında gecikmeli bağımlı değişken bulunmaması durumunda otokorelasyon sorunun olup olmadığını 
ortaya koymak için yapılan testtir. Analiz sonucunda D-W istatistik değeri 1.9892 olması modellerin otokorelasyon sorunu yaşamadığını ifade etmektedir. Modellerde varyans sorunu olup olmadığını belirleyebilmek için LMh istatistiği yapılmış olup olasılık değerinin 0.010 ve 0.034 çıması modellerde değişen varyans sorunun olduğu bir başka diğer bir deyisle hata terimlerinin sabit varyanslı olmadığını göstermektedir. Değişen varyans probleminin giderilmesi için White crosssection düzeltmesi yapılmıştır.

Tablo 5: İlgili Modele İlișkin İstatistiki Sonuçlar

\begin{tabular}{|c|c|c|c|}
\hline Değişkenler & Model & & \\
\hline & Katsay 1 & Std.Hata & t-ist \\
\hline $\mathrm{c}$ & -0.234 & 0.845 & $\begin{array}{l}-1.765 \\
(0.010)\end{array}$ \\
\hline ENF & -0.497 & 3.654 & $\begin{array}{l}-1.945 \\
(0.003)\end{array}$ \\
\hline FA & 0.045 & 0.984 & $\begin{array}{c}0.645 \\
(0.654)\end{array}$ \\
\hline KV & 0,265 & 0.634 & $\begin{array}{l}-5.652 \\
(0.002)\end{array}$ \\
\hline BDR & $-0,276$ & 0.121 & $\begin{array}{l}-3.687 \\
(0.018) \\
\end{array}$ \\
\hline BTLM & -0.727 & 0.756 & $\begin{array}{l}-3.675 \\
(0.010) \\
\end{array}$ \\
\hline PR & 0.287 & 0.681 & $\begin{array}{l}4.987 \\
(0.001)\end{array}$ \\
\hline $\mathrm{R}^{2}$ & & & 0.791 \\
\hline Düzeltilmiş $\mathrm{R}^{2}$ & & & 0.862 \\
\hline $\mathrm{F}$ istatistiği & & & $\begin{array}{l}4.1267 \\
(0.003)\end{array}$ \\
\hline $\mathrm{D}-\mathrm{W}$ istatistiği & & & 1.9892 \\
\hline Hausman Testi & & & $\begin{array}{l}1.603 \\
(0.754)\end{array}$ \\
\hline LMh istatistiği & & & $\begin{array}{l}100.543 \\
(0.010)\end{array}$ \\
\hline Wooldridge istatistiği & & & $\begin{array}{l}9.108 \\
(0.001) \\
\end{array}$ \\
\hline
\end{tabular}

Not: Parantez içi değerler anlamlılık seviyelerini ifade etmektedir.

Tablo 5'e göre analiz açısında kurulan her iki modelin $\mathrm{F}$ testi anlamlı ve $\% 99$ güvenirlilik seviyesinde modelin anlamlı olduğuna işaret etmektedir. $\mathrm{R}^{2}$ değeri birinci modelde 0.79 olduğu görülmektedir. $\mathrm{Bu}$ değerler bağımsız değişkenlerdeki değişimlerin bağımlı değişkeni açıklama gücünün birinci model için 0.79'nu açıklayabildiğini anlamına gelmektedir. Bu durum genel olarak analize tabi tutulan modelde yer alan bağımsız değişkenlerin türev ürün kullanımı kayda değer bir şekilde açıklayabildiğini göstermektedir.

Tablo 5'e analiz sonuçlarına bakıldığında ilk modelde faiz oranı değişkeni dışında yer alan tüm bağımsız değişkenlerin, bağımlı değişken döviz swap miktarı üzerinde istatistiki olarak anlamlı bulunmuştur. Bir başka ifadeyle bu değişkenlerden bilanço dışı riskler, bankaların TL mevduatları ve enflasyon değişkenleri ile döviz swapları arasında istatistiki olarak anlamlı ve negatif, piyasa riski ve kur riski değişkenlerinin ise döviz swapı üzerinde istatistiki olarak anlamlı ve pozitif bir etkisinin olduğu görülmektedir. Buna göre piyasa riski ve kur volatilitesindeki \%1'lik bir artış döviz swap1 üzerinde sırasıyla $\% 0.28$ ve $\% 26^{\prime}$ lik bir artışa neden olacaktır. Buna karşın bilanço dış1 riskler, bankaların TL mevduatları ve enflasyon değişkenlerinde \%1'lik bir artış döviz swapı üzerinde sırasıyla $\% 0.27, \% 0.72$ ve $\% 0.49^{\prime} l u k$ bir azalışa neden olacaktır. 


\section{Bulgular}

Yapılan analiz sonucunda döviz swap miktarının kullanımı ile faiz oranı değişkeni dışında istatistiki olarak anlamlı ilişkiler bulunmuştur. Döviz swap miktarı kullanımını negatif yönde etkileyen değişkenlerin bilanço dışı riskler, bankaların TL mevduatları ve enflasyon iken, pozitif yönde etkileyen değişkenler ise piyasa riski ve kur riskidir. Faiz oranı ile döviz swap kullanımı arasında istastiki olarak anlamlı bir sonuç bulunmamıştır.

Çalışma sonucunda elde edilen sonuçlar ile literatür çalışmaları karşılaştırıldığında, bilanço dışı riskler ile türev ürün arasında anlamlı, anlamsız, pozitif ve negatif her türlü ilişkinin ortaya koyulduğu çalışmalar olmasına, genel olarak beklentinin türev ürün kullanımı sonucunda ortaya çıan bilanço dışı risk arttığında türev ürün kullanımı azaldığı gözlemlenmiştir. Bu sonuç çalışmamızda beklentilere uygun ve anlamlı bir şekilde gerçekleşmiştir.

İlgili modelimizde enflasyon ve türev ürün kullanımı arasında negatif yönde ve anlamlı bir ilişki tespit edilmiş̧ir. Literatür çalışmalarında Hassan ve Khasawneh (2009), ; enflasyon ve swap kullanımı arasında negatif bir ilişki, Anbar ve Alper (2011) herhangi bir ilişki bulamadıkları ve Bailey ve Chan (1993) ise pozitif yönde bir ilişki bulmalarına karşın, çalışmada enflasyon ve döviz swap kullanımı arasında beklentilere uygun bir şekilde negatif bir ilişki bulunmuştur. Bu durum özellikle Türkiye'de enflasyonun düşüş gösterdiği dönemlerde bankaların getiri elde etmek amacıyla alım satım amaçlı türev ürün kullanımı arttırmaları çalışma sonuçlarıyla örtüşmektedir.

Bir diğer değişkenlerden kuru volatilitesi ile döviz swap miktarı kullanımında Shiu vd. (2012) pozitif bir ilişki, Yip ve Nguyen (2012) ise anlamlı bir ilişki bulamamalarına karşın, araştırmamızda pozitif ve anlamlı bir ilişkinin mevcudiyeti bulunmuştur. Bu durum beklentiler ile uyumlu olmasının yanında özellikle Türkiye'de özellikle kur volatilitesinin yüksek olduğu durumlarda bankaların hedge etme amaçlı döviz swaplarına çoğu zaman başvurdukları görülmüsstür. Özellikle Türkiye'de son günlerde makroekonomik koşullarında yaşanan olumsuzluklar, siyasi istikrarsızlık ülkeyi yabancı gözüyle daha riskli hale görülmeye başlanmasına neden olmuştur. Yabancılar daha riskli hale gelen bir ülkenin para birimi ile borçlanmak istemedikleri için TL ihtiyaçlarını Londra swap piyasasında sağlamaya çalıştılar. Fakat swap işlemlerine getirilen sınırlamalar TL'nin likidite sıkışıklığına neden olup, swap faizlerinin artmasına neden olmuştur. Burada dikkat edilmesi gereken nokta döviz kurları ve faizlerin kontrolü kısa vadeli operasyon uygulamalar ile değil istikrar, üretim, demokrasi ve istihdam gibi unsurlara bağlı olduğu unutulmamalıdır.

Bankaların TL mevduat toplamının artması, risk primini azaltmakta ve olası volatilite zamanlarında bankalar açısından bir güven unsuru olarak görülmektedir. Özellikle son zamanlarda bankaların yüksek faiz getirisi sunmaları sonucunda TL mevduatlarındaki yaşanan artışa karşın Türkiye'de bankacılık sektörü bu artışı firsata çevirip gelirlerini çeşitlendirerek karlılıklarını arttırmak için alım satım amaçlı türev ürün kullananımı arttırabilecekken, bu firsatları tepip sadece kuru riskine karşın sürekli döviz talepleri yaratmaları ve döviz miktarlarını arttırmaları döviz kurunu sürekli yüksek tutmaktadır.

Çalışmada yapılan analizler sonucunda türev ürün kullanımında makroekonomik faktörlerin etkilediği ortaya çıkmıştır. Bunun yanında türev ürün kullanımı ve makroekonomik değişkenler ele alındığında Türk bankacılık sektörünün türev ürün kullanımının hedge amacından ziyade alım satım amacıyla kullanıldığı ortaya çıkmıştır.

\section{Sonuç ve Tartışma}

Finansal piyasaların en önemli oyuncularından olan bankalar türev ürün kullanımının en yoğun bir şekilde olduğu kurumlardır. Bankaların türev ürünleri kullanma amaçları her ne kadar riskten korunma amaçlı gibi görünse de y1llar itibariyle en çok alım satım amaçlı kullanıldığ görülmektedir. Bunun yanında bankalar ürün çeşitliliği arttırmak, aracılık faaliyetleri ve karlılık

\section{Turkish Studies - Social Sciences}

Volume 14 Issue 5, 2019 
amacıyla da türev ürünleri kullanmaktadırlar. Bankalar karşılaşmış oldukları risklerden kaynaklanan belirsizlikleri azaltmak ve finansal risklere karşı korunma amacıyla ürün çeşitlendirme, döviz pozisyonu kontrolü, aktif-pasif yönetimi ve türev ürün kullanarak riskten korunmaya yönelmektedirler.

Dünyada son zamanlarda finansal kurumların mali tablolarında yer alan türev ürün kullanımında ki artış, kurumların mali yapılarında risk yönetimi konusuna giderek daha önem verdiklerinin göstergesi niteliğini taşımaktadır. Özellikle Türk bankacılık sektöründe son zamanlarda kur riskinde ki artış ve piyasalarda ki gelişmeler bankaların maruz kaldıkları riskleri arttırmış ve bankaların riskten korunma amaçlı türev ürün kullanımında kayda değer artışlar gözlemlenmiştir. Yaşanan gelişmeler sonucunda TL türev işlem hacminin, döviz türev işlem hacminin gerisinde kaldığ 1 gözlemlenmiş̧ir. Türk bankacılık sektöründe türev ürün kullanımına bakıldığında, en çok kullanılan türev ürünün swap işlemleri olduğu ve swap işlemleri açısından ise döviz swaplarının tercih edildiği görülmektedir. Özellikle son yıllarda döviz swap işlemlerinde ki artış kur riski ve kar beklentileri ile örtüşmektedir.

Türk bankacılık sektöründe türev ürün kullanımını etkileyen faktörlerin belirlenmesi açısından, türev ürünler içerinde en büyük paya sahip döviz swapları kullanımını etkileyen makroekonomik değişkenlerin belirlenebilmesi amacıyla panel veri analizinden yararlanılmıştır. Çalışmada yapılan analizler sonucunda faiz oranı dışında yer tüm makroekonomik parametrelerden döviz swap kullanımını etkilediği gözlemleniştir. Çalışmada kullanılan parametrelerin yapılan literatür çalışmalarında, hem yurt içi hem de yurtdışında yapılan analizlerde farklı etkileri olduğu görülmüştür. Bu farklılıklar; çalışmaya konu olan dönemlerdeki ekonomik konjonktür, ülkelerin ekonomik yapıları, bankacılık sektörünün mali yapısı ve bankacılık sektörüne ait uygulamada ki farklılıktan kaynaklanabilmektedir.

Son yıllarda hem Türkiye'de hem de yurdışı piyasalarda yaşanan gelişmeler sonucunda Türk bankacılık sektörü döviz swap işlemleri ile ilgili makroekonomik parametrelerin ilişki ortaya koyulması, bankacılık sektörü karar vericileri açısından çalışmanın yararlı olabileceği düşünülmektedir.

\section{KAYNAKÇA}

Anbar, A., ve Alper, D. (2011). Bankaların Türev Ürün Kullanım Yoğunluğunu Etkileyen Faktörlerin Belirlenmesi. Muhasebe ve Finansman Dergisi.

Bailey, W., ve Chan, K. C. (1993). Macroeconomic Influences and the Variability of the Commodity Futures Basis. The Journal of Finance, 48(2), 555-573.

Baltagi, B. H. (2005). Econometric analysis of panel data, 3rd ed. John Wiley and Sons Ltd.

Berk, N. (2007). Finansal Yönetim. İstanbul: Türkmen Kitapevi, 9. Baskı.

Bilman, A. S. (2014). Ticari Açıklık Büyüme Etkileşimi: Panel Veri Analizi ve Ülkelerarası Karşılaştırma (Interaction between Trade Openness and Growth: Panel Data Analysis and Comparison between Countries). Doctoral Thesis, 169. İzmir: Dokuz Eylül University, Department of Economics.

Dubofsky, D. A. (2001). Options and Financial Futures. Mc Garw-Hill.

Ederington, L. H., ve Lee, J. H. (1993). How Markets Process Information: News Releases and Volatility. The Journal of Finance(48).

Elder, J., Miao, H., ve Ramchander, S. (2012). Impacts of Macroeconomic News on Metal Futures. Journal of Banking ve Finance . 
Ersan, İ. (1997). Finansal Türevler,. İstanbul: Literatür Yayıncılık.

Greene, W. H. (2003). Econometric Analysis (5. Edition). New Jersey: Prentice Hall.

Hassan, M., ve Khasawneh, A. (2009). The Determinants of Derivatives Activities in U.S. Commercial Banks. Network Financial Institute.

Horne, J. C. (1985). Of Financial Innovations and Excesses. Journal of Finance, 40(3), 621-31.

Hsiao, C. (2002). Analysis of Panel Data (2. Edition). New York: Cambridge University Press.

Jorion, P. (2011). Financial Risk Manager-Handbook. Canada: Wiley Finance (sixth edition).

Khan, Z. (2016). Characteristics of Interest Rate Swap End-User Commercial Banks:Evidence from Pakistan. Market Forces Collage of Management Sciences.

Kim, S., ve Koppenhaver, G. (1992). An Empirical Analysis of Bank Interest Rate. Journal of Financial Services Research(7).

Kohlscheen, E., ve Andrade, S. (2013). Official Interventions through Derivatives: Affecting the Demand for Foreign Exchange. The Banco Central do Brasil Working Paper.

Kolb, R., ve Overdahl, J. (2002). Financial Derivatives. New Jersey:: John Wiley ve Sons.

Levin, A. L. (2002). Asymptotic and finitesample properties. Journal of Econometrics, 108, 1-24.

Önder, K. (2017). Pamuk Arzını Etkileyen Faktörlerin Panel Veri ile Analizi. Eskişehir Osmangazi Üniversitesi İIBBF Dergisi, 12(1), 83- 98.

Özgümüs, H., Korkmaz, T., ve Çevik, E. (2013). Makroekonomik Faktörlerin Vadeli İslem (Futures) Sözlesmelerine Etkisi: VOB’ta Bir Uygulama. BDDK Bankacılık ve Finansal Piyasalar Dergisi.

Shiu, Y., ve Moles, P. (2010). What Motivates Banks to Use Derivatives: Evidence from Taiwan. Journal of Derivatives.

Shiu, Y., Wang, C., Adams, A., ve Shin, Y. (2012). On the Determinants of Derivative Hedging by Insurance Companies: Evidence from Taiwan. Asian Economic and Financial Review.

Silber, W. L. (1983). The Process of Financial Innovation. The American Economic Review, 73, 8995.

Sinkey, J., ve Carter, D. (2001). Evidence on the financial characteristics of banks that do and do not use derivatives. The Quarterly Review of Economics and Finance, 40(4), 431-449.

Straathof, B., ve Calio, P. (2012). Currency Derivatives and the Disconnection Between Exchange Rate Volatility and International Trade. CPB Discussion Paper.

Thakral, C., ve Kumar, S. (2007). Use of Interest Rate Swaps by Commercial Banks:An Analysis of Determinants. Indian Institute of Management.

Wooldridge, J. (2009). Introductory econometrics: a modern approach (4th. Ed.). Canada: South Western Cengage Learning.

Yılgör, A. G. (2019, 07 05). Bağımsız İletişim Ağı. https://m.bianet.org/bianet/ekonomi/206897doviz-kuru-dalgalanmalari-ve-swap-islemleri adresinden alındı

Yip, W., ve Nguyen, H. (2012). Exchange Rate Exposure and the Use of Foreign Currency Derivatives in the Australian Resources Sector. Journal of Multinational Financial Management. 